\title{
Forceps deliveries and fetomaternal outcome in modern obstetrics
}

\author{
Sarda Devi Okram*, Kalpana Betha, Jothsna Bodhanapati, Koorapati Tejasri
}

Department of Obstetrics and Gynecology, Mediciti Institute of Medical Sciences, Medchal, Hyderabad, India

Received: 09 October 2019

Accepted: 31 October 2019

\section{*Correspondence:}

Dr. Sarda Devi Okram,

E-mail: drokramsarda@gmail.com

Copyright: (C) the author(s), publisher and licensee Medip Academy. This is an open-access article distributed under the terms of the Creative Commons Attribution Non-Commercial License, which permits unrestricted non-commercial use, distribution, and reproduction in any medium, provided the original work is properly cited.

\section{ABSTRACT}

Background: In modern obstetrics practice has witnessed an increase in the caesarean section rates everywhere. The incidence of instrumental deliveries varies between $10-12 \%$ in UK. The incidence of instrumental deliveries varies between $2.7-5 \%$ in India. There is an urgent need to reintroduce instrumental need in the modern obstetrics. Instrumental delivery is one of the basic functions of emergency care according to WHO. This study was done to know the prevalence, indications and fetal outcomes of forceps deliveries.

Methods: A retrospective study was conducted at a tertiary teaching hospital, India from January 2014 to December 2018. All cephalic singleton pregnant mothers who underwent forceps delivery after 28 weeks were included. All the forceps delivery done in twins and breech vaginal delivery were excluded. Demographic data, Indication of forceps delivery, maternal complications of forceps delivery like episiotomy extension, cervical tear, vaginal wall tear, PPH and neonatal outcome like low birth weight, NICU admissions, stillbirth, APGAR score at 1 and 5 minutes were recorded. Equal number of mothers of reproductive age group 20-45 ages who underwent normal non breech vaginal deliveries were randomly selected as control.

Results: The prevalence of forceps delivery was 5.25\%. The most common indication was fetal distress (55\%). Most of the mothers were primigravidas in age group 20-30 years ( $<<0.001)$. Regarding the neonatal outcome, $72 \%$ of the babies were having weight $>2.5 \mathrm{kgs}$. APGAR $<7$ at 1 and $5 \mathrm{~min}$ was not significant.

Conclusions: As fetal distress is the most common indication, every obstetrician should learn the skill of forceps delivery and it should not be a dying art.

Keywords: Forceps, Low birth weight, Postpartum haemorrhage

\section{INTRODUCTION}

Instrumental deliveries are vaginal deliveries accomplished with the use of vacuum device or forceps. Instrumental deliveries are an important part of obstetric practice which enables the obstetrician to deliver vaginally and thereby reducing the caesarean rates. Modern obstetric practice has witnessed an increase in the caesarean section rates everywhere. There are ways of preventing primary caesarean delivery and forceps delivery is one of them. ACOG and the Society for maternal fetal medicine address the concept of preventing the primary caesarean delivery. ${ }^{1}$

The incidence of instrumental deliveries differs among different locations and obstetricians too. The incidence varies between $10-12 \%$ in UK and $10-15 \%$ in US. ${ }^{2,3}$ The incidence of instrumental deliveries varies between 2.7$5 \%$ in India. ${ }^{4,5}$ There is an urgent need to reintroduce instrumental need in modern obstetrics. Instrumental delivery is one of the basic functions of emergency care according to WHO. ${ }^{6}$ So, facilities should be made 
available and easily accessible not only in labour wards and operation theatres but also in ambulances and casualty wards.

The aim of the present study was to assess the prevalence of forceps deliveries and its fetomaternal outcome among all the births occurring at Mediciti Institute of Medical Sciences (MIMS), a rural tertiary teaching hospital in Telangana in a period of 5 years from January 2014 to December 2018.

\section{METHODS}

This is a retrospective study conducted at Mediciti Institute of Medical Sciences, a rural tertiary teaching hospital located $35 \mathrm{~km}$ from the city of Hyderabad in Telangana state, India. All forceps deliveries delivered after 28 weeks of gestation at MIMS in during a period of 5 years from January 2014 to December 2018 were included.

All deliveries in the hospital and pregnancy outcomes are recorded in the birth register. The hospital records of all patients who had forceps deliveries were obtained.

\section{Inclusion criteria}

- $\quad$ Singleton pregnancy

- Cephalic presentation

- $\quad$ Forceps delivery.

\section{Exclusion criteria}

\section{- Twin deliveries}

- Breech deliveries.

Using each woman's unique medical record number, case files were obtained and data on demographic variables, indication of forceps delivery, maternal complication of forceps delivery like episiotomy extension, cervical tear, vaginal wall tear, PPH and neonatal outcome like early neonatal death, NICU admissions, stillbirth, APGAR score at 1 and 5 minutes were recorded for all the cephalic singleton forceps deliveries.

Gestational age was calculated using last menstrual period and confirmed by dating scan. Forceps deliveries were performed using short curved outlet Wrigley's forceps. Criteria for application of outlet forceps were scalp visible at the introitus without separating labia, fetal skull has reached pelvic floor, Sagittal suture in anteroposterior diameter or right or left occiput anterior or posterior position. Fetal head at or on perineum. Rotation does not exceed 45 degrees. ${ }^{7}$

Equal number of mothers of reproductive age group 2045 ages who underwent normal non breech vaginal deliveries were randomly selected as controls. The indications of instrumental vaginal delivery were broadly based on 4 common indications. ${ }^{8}$

- Prolonged second stage of labour (Defined as- In Nulliparous as lack of progress of labour for 3 hours with regional anesthesia or 2 hours without anesthesia. In multiparous as lack of progress of labour for 2 hours with regional anesthesia or 1 hours without anesthesia)

- Non reassuring fetal testing (suspicion of immediate or potential fetal compromise is an indication for the operative vaginal delivery)

- Elective shortening of second stage of labour (In maternal cardiovascular /neurological disorders)

- Maternal exhaustion (largely subjective and not well defined).

\section{Statistical analysis}

Data was collected and tabulated as shown in results. Statistical analysis was done using Microsoft Excel. Each parameter's frequency and percentage were calculated and analyzed.

\section{RESULTS}

A total of 513 forceps deliveries out of 9765 deliveries occurred at Medicate Institute of Medical Science from January 2014 to December 2018. The prevalence rate is $5.25 \%$ (Table 1).

Table 1: Year wise prevalence of forceps delivery from January 2014 to December 2018.

\begin{tabular}{|llll|}
\hline Year & Forceps & Normal vaginal & Prevalence \\
\hline 2014 & 87 & 2600 & $3.4 \%$ \\
\hline 2015 & 88 & 1855 & $4.6 \%$ \\
\hline 2016 & 133 & 2073 & $6.4 \%$ \\
\hline 2017 & 104 & 1847 & $5.7 \%$ \\
\hline 2018 & 101 & 1390 & $7.2 \%$ \\
\hline Total & $\mathbf{5 1 3}$ & $\mathbf{9 7 6 5}$ & $\mathbf{5 . 2 5 \%}$ \\
\hline
\end{tabular}

Table 2: Age distribution of woman who delivered by forceps.

\begin{tabular}{|lll|}
\hline Age in years & Forceps & Normal vaginal \\
\hline$<19$ & $60(12 \%)$ & $28(5 \%)$ \\
\hline $20-25$ & $323(63 \%)$ & $344(67 \%)$ \\
\hline $26-30$ & $107(20 \%)$ & $118(23 \%)$ \\
\hline $31-35$ & $23(4 \%)$ & $19(3.7 \%)$ \\
\hline $36-40$ & 0 & $3(0.5 \%)$ \\
\hline $41-45$ & 0 & $1(0.1 \%)$ \\
\hline
\end{tabular}

Majority of mothers (83\%) who required forceps for delivery were between $20-30$ years. Ninety-three percent were booked cases. Only $27 \%$ were multigravida (Table $2,3,4)$. 
Fetal distress $(55 \%)$ was the most common indication for which forceps was applied, followed by cutting short second stage of labor (Table 5). Maternal complications were seen in $17.5 \%$ of cases. The most common complication seen was PPH (5.8\%) (Table 6).

Table 3: Booking status of woman who delivered by forceps.

\begin{tabular}{|lllll|}
\hline $\begin{array}{l}\text { Booking } \\
\text { status }\end{array}$ & \multicolumn{1}{c}{ Forceps } & $\begin{array}{l}\text { Normal } \\
\text { vaginal }\end{array}$ & OR & P-value \\
\hline Un booked & $37(7 \%)$ & $30(6 \%)$ & 1.251 & 0.3772 \\
\hline Booked & $476(93 \%)$ & $483(94 \%)$ & & \\
\hline
\end{tabular}

Table 4: Parity status of woman who delivered by forceps.

\begin{tabular}{|lllll|}
\hline Parity & Forceps & $\begin{array}{l}\text { Normal } \\
\text { vaginal }\end{array}$ & OR & P. value \\
\cline { 1 - 3 } Primi & $375(73 \%)$ & $222(43 \%)$ & 3.53 & $<0.0001$ \\
\hline Multi & $139(27 \%)$ & $291(57 \%)$ & & \\
\hline
\end{tabular}

Table 5: Indication for forceps application.

\begin{tabular}{|ll|}
\hline Indication & Forceps \\
\hline Fetal distress & $283(55 \%)$ \\
\hline Poor maternal efforts & $106(21 \%)$ \\
\hline To shorten $2^{\text {nd }}$ stage & $124(24 \%)$ \\
\hline
\end{tabular}

Table 6: Maternal complications/morbidities.

\begin{tabular}{|lll|}
\hline Morbidity conditions & Number & Percentage \\
\hline Postpartum hemorrhage & 30 & $5.8 \%$ \\
\hline $\begin{array}{l}\text { Vaginal and cervical } \\
\text { lacerations }\end{array}$ & 25 & $4.8 \%$ \\
\hline $\begin{array}{l}\text { Third and fourth degree } \\
\text { perineal tear }\end{array}$ & 20 & $3.8 \%$ \\
\hline Paraurethral tear & 8 & $1.5 \%$ \\
\hline Vulvo vaginal hematoma & 7 & $1.3 \%$ \\
\hline
\end{tabular}

Table 7: Fetal outcome of woman who delivered by forceps.

\begin{tabular}{|lll|}
\hline Fetal outcome & Forceps & Normal vaginal \\
\hline IUD & $3(0.5 \%)$ & $2(0.3 \%)$ \\
\hline Mother side & $252(49 \%)$ & $314(61.2 \%)$ \\
\hline NICU & $257(50.5 \%)$ & $197(38.4 \%)$ \\
\hline
\end{tabular}

Table 8: Birth weight of the forceps delivered babies.

\begin{tabular}{|lll|ll|}
\hline $\begin{array}{l}\text { Baby } \\
\text { weight in kg }\end{array}$ & Forceps & $\begin{array}{l}\text { Normal } \\
\text { vaginal }\end{array}$ & OR & P value \\
\hline$<2.5$ & $142(28 \%)$ & $85(17 \%)$ & \multirow{2}{*}{1.92} & $<0.0001$ \\
\hline$>2.5$ & $371(72 \%)$ & $428(83 \%)$ & & \\
\hline
\end{tabular}

NICU admission was noted in $50.5 \%$ of the cases. Birth weight $<2.5 \mathrm{kgs}$ were noted in only $28 \%$ of the cases.
Low Apgar score $<7$ in one and five minutes were noted in only $15 \%$ and $2.3 \%$ respectively (Table 7,8 and 9 ).

Table 9: APGAR Score of the forceps delivered babies

\begin{tabular}{|lllll|}
\hline $\begin{array}{l}\text { Apgar } \\
\text { score }\end{array}$ & Forceps & $\begin{array}{l}\text { Normal } \\
\text { vaginal }\end{array}$ & OR & $\begin{array}{l}\text { P. } \\
\text { Value }\end{array}$ \\
\hline $1^{\prime}<7$ & $75(15 \%)$ & $30(6 \%)$ & 0.2 & 0.14 \\
\hline $5^{\prime}<7$ & $12(2.3 \%)$ & $1(0.1 \%)$ & & \\
\hline
\end{tabular}

\section{DISCUSSION}

In the present study, the prevalence was $5.25 \%$ which is higher than that of other studies, Prameela RC et al $(2.2 \%)$, Lamba A et al $(4.2 \%))^{4,5}$ But the prevalence rate in the current study is very much lower than $8.5 \%$ recommended by RCOG and also lower than developed countries. $^{8}$ The low prevalence in the current study may be due to the reluctance among the obstetrician to use forceps for the fear of litigation following the poor maternal and fetal outcome after forceps. Another reason for low prevalence is due to low use in low resource setting universally as seen in study done by Ameh CA et al. ${ }^{9}$

Most of the mothers who had forceps delivery, 430 (83\%) belong to age group 20-30 years which is same in other studies Lamba A et al (40\%), Shameel $\mathrm{F}$ et al $(87 \%)$, Aliyu LD et al (62\%) and Demissie K. Rhoads GG et al. ${ }^{5,10,12}$ The reason of more forceps delivery in age group of 20-30 years of age may be due to the early marriage of women resulting in their first pregnancy in their twenties.

Most Mothers were primigravida $375(73 \%)$ and it is similar to other studies Lamba A et al $(68 \%)$, Shameel F et al (57\%), Aliyu LD et al (52\%), Aktar S et al. ${ }^{5,10,11,13}$ The prevalence of more forceps delivery in primigravida may be because of rigid perineum, minor degree of relative cephalo pelvic disproportion. ${ }^{14}$

Regarding the maternal outcome, the maternal injuries were noted in $17.5 \%$ of the cases and it was higher than study done by John LB et al except vulvovaginal hematoma $(1.3 \%)$ in the current study while it is $2.8 \%$ (Lamba A et al). ${ }^{15} \mathrm{PPH}$ was most common complication noted in the present study.

Fetal distress $283(55 \%)$ was the most common indication and is similar to the study done by Lamba A et al (54\%), Nikolov A et al $(78.1 \%)$ and Yeomans ER et al but is in contrary to the study done by Shameel $\mathrm{F}$ et al where Fetal distress accounted for only $11 \%$ cases and $70 \%$ were due to prolonged second stage. ${ }^{5,16,17} 50.5 \%$ of the babies had NICU admission which is much higher than the study done by Shameel $\mathrm{F}$ et al $(27 \%)$, Prapas $\mathrm{N}$ et al $(14.43 \%){ }^{8,18}$ The higher number of NICU admission again may have been contributed by combine fear of the paediatricians and the obstetrician for litigation rather than pure indication as only $15 \%$ and $2.3 \%$ of the forceps 
delivery had low Apgar score of $<7$ in 1 mins and 5 mins respectively.

Regarding the neonatal outcome, only $28 \%$ of the babies were having weight $<2.5 \mathrm{kgs}$ showing that instrumental deliveries were more frequent in infants with higher birth weight and this finding is similar to study done by Lamba A et al and Wu Wen $\mathrm{S}$ et al. ${ }^{5,19}$

\section{CONCLUSION}

Decision to proceed with a forceps delivery when a spontaneous vaginal delivery is not possible must be based not only upon maternal and fetal risks but also on the expertise of attending obstetrician. As fetal distress is the most common indication, every obstetrician should learn the skill of forceps delivery and it should not be a dying art.

Funding: No funding sources Conflict of interest: None declared

Ethical approval: The study was approved by the Institutional Ethics Committee

\section{REFERENCES}

1. Spongy CY, Berghella V. Wenstrom KD. Preventing the first ceaserean delivery. Obstet Gynecol. 2012;120:1181-93.

2. Lindow SW, Hayashi R. Assisted vaginal delivery high risk pregnancy, 4th ed; 2011;72;1245-1259.

3. ACOG Practice Bulletin. Clinical management guidelines for obstetricians gynecologists. Pregestational Diabetes. 2005;105:675-685

4. Prameela RC, Asha MB, Prajwak S. Outcome of instrumental vaginal deliveries in referred cases. J Evolution Med Dental Sci. 2015;4(19):3275-80.

5. Lamba A, Kaur R, Muzafar Z. An observational study to evaluate the maternal and neonatal outcome of forceps delivery in a tertiary care government hospital of cosmopolitan city of India. IJRCOG. 2016;5(2):292-5.

6. Maine D, Wardlaw T, Ward V, McCarthy J, Birnbaum A, Akalin MZ, et al. Guidelines for monitoring the availability and use of obstetric services. World Health Organization Geneva; 1997.

7. Operative vaginal delivery. ACOG Technical Bulletin Number 196-- August 1994 (replaces No.
152, February 1991). Int J Gynaecol Obstet. 1994 Nov;47(2):179-85.

8. The American College of Obstetricians and Gynecologists, authors Operative Vaginal Delivery. Washington, DC: ACOG; 2000. (Practice Bulletin No. 17); 2000:1-7.

9. Ameh CA, Weeks AD. The Role of Instrumental Vaginal delivery in low resource settings. BJOG. 2009;116(1):22-5.

10. Shameel F, Bava A. Instrumental vaginal deliveries at tertiary centre. IJRCOG. 2016;5(12):4146-50.

11. Aliyu LD, Kadas AS, Hauwa MA. Instrumental vaginal delivery in bauchi, northeast Nigeria. J West Afr Coll Surg. 2011;1(4):18-27.

12. Demissie K, Rhoads GG, Smulian JC. Operative vaginal delivery, neonatal, infant adverse outcomes: population based retrospective analysis. BMJ. 2004:4:329-34.

13. Akhtar S. Comparison of maternal and infant outcome between vacuum extraction and forceps deliveries. Pak Armed Force Med J. 2006;2(1):2531.

14. Karacam Z, Eroğlu K. Effects of episiotomy on bonding and mothers' health. J Advanced Nursing. 2003;(43)4:384-94.

15. Lopamudra B, John S, Nischintha, Ghose S. Outcome of forceps delivery in a teaching hospital: A 2 year experience. JNSBM. 2014;5(1):155-7.

16. Nikolov A, Nashar S, Atanasova M, Dimitrov A. Indications for vaginal delivery with forceps application. Akush Ginekol (Sofiia). 2011;50:3-12.

17. Yeomans ER. Operative vaginal delivery. Obstet Gynecol. 2010;115:645-53.

18. Prapas N, Kalogiannidis I, Masoura S. Operative vaginal delivery in singleton term pregnancies: short term maternal and neonatal outcomes. Hippokratia. 2009;13:41-5.

19. Wen WS, Shiliang L, Kramer SM, Marcoux S, Ohlsson A, Sauvé R, et al. Comparison of maternaland infant outcomes between vacuum extraction and forceps deliveries. Am J Epidemiol. 2001;153:103-7.

Cite this article as: Okram SD, Betha K,

Bodhanapati J, Tejasri K. Forceps deliveries and fetomaternal outcome in modern obstetrics. Int $\mathbf{J}$ Reprod Contracept Obstet Gynecol 2019;8:4862-5. 